\title{
Research on Factors Contributing to the Fluctuating Copper Price Based on Copper Supply and Demand
}

\author{
Zhang Yan $^{1}$, Shen Weiwei ${ }^{2, *}$ \\ ${ }^{1}$ Tongling University, Tongling 244000, China \\ ${ }^{2}$ Tongling Central Branch of the People's Bank of China, Tongling 244000, China \\ *Corresponding author: Shen Weiwei
}

Keywords: Fluctuating Price of Copper, Supply and Demand, Empirical Research, Influencing Factors.

\begin{abstract}
This paper concludes that there is a long-term and stable equilibrium relationship between copper price and supply and demand in China through empirical research on supply and demand of copper in China. The equilibrium relationship is mainly affected by refined copper output and scrap copper import value. However, Consumer Price Index has the biggest impact on Copper prices.
\end{abstract}

\section{Introduction}

China has always been a major country in copper consumption and its apparent consumption accounts for about $40 \%$ of the world's total consumption. In recent years, the price of copper has experienced sharp ups and downs. The general trend of copper prices is still showing a downward tendency, mainly due to the sluggish global economy. In order to understand the factors contributing to the fluctuating copper price, this paper studies supply and demand of copper to reveal the mechanism of the fluctuating copper price. Due to China's large consumption and import in copper, supply-side factors of copper include refined copper imports, refined copper output, copper scrap imports, and copper futures at the Shanghai Futures Exchange and so on. In addition to copper consumption, the demand of the downstream industries is also an important factor affecting the copper price. This paper mainly analyses the real estate industry and the price factor, so demand-side factors of copper include refined copper consumption, real estate investment and the Consumer Price Index.

\section{Copper market}

In 2016, the global refined copper production was about 23.41 million tons, a year-on-year increase of $2.3 \%$. Asia ranked first in the production of refined copper, while America still ranked first in the wet copper production. China continues to hold the position of the largest copper smelting country and its output keeps growing. Indian smelter in Asia recovered its production capacity. Put into operation by the new wet-copper mine, the output growth rate of Congo (DRC) was basically equal to that of China. The major copper producing countries such as Chile and Japan are affected by the drop in the price of copper so the output shows a different magnitude of decline.

The consumption of refined copper was 23.46 million tons, a year-on-year increase of $1.8 \%$ in 2016 . The global growth of refined copper consumption mainly came from the Asian region. China was still the key region contributing to the growth of China's refined copper consumption.

According to the data from China Nonferrous Metals Industry Association, China's refined copper output reached 8.436 million tons in 2016, a year-on-year increase of 6\%. Among which the output of refined copper in Jiangxi, Anhui, Shandong, Gansu, Yunnan and Hubei Province was above 500,000 tons respectively. According to statistics from China's General Administration of Customs, the import of refined copper in 2016 was 3.629 million tons, a slightly year-on-year down of 1.3\%. Even in this case, the refined copper imports remain its peak. In 2016, a total of 426,000 tons of refined copper were exported, a substantial increase of $101.2 \%$ over the same period of last year. 


\section{Empirical analysis}

\subsection{Variable Selection and Data Description}

A total of 72 monthly sample data from January 2011 to December 2016 are selected from WIND Consulting, ICSG website and China Statistical Yearbook. This paper takes the monthly average price of 1 \# electrolytic copper in the spot market of Shanghai Nonferrous Metals as the copper price index, which is recorded as EC; the imports of refined copper, the production of refined copper, the import amount of scrap copper and the copper inventory in the Shanghai Futures Exchange are recorded as IC, PC, FC and KC respectively; consumption of refined copper is recorded as XC; real estate investment, measured by national housing climate index, is recorded as GF; Consumer Price Index is recorded as CPI.

In order to eliminate the impact of the Spring Festival factor, the National Bureau of Statistics does not release the national housing climate index data for January of each year in January. So this paper replaces the data in January each year with February data. In addition, in order to eliminate heteroscedasticity, this paper takes logarithm of the above indicators. Logarithmic data timing diagram is shown in Figure 1.

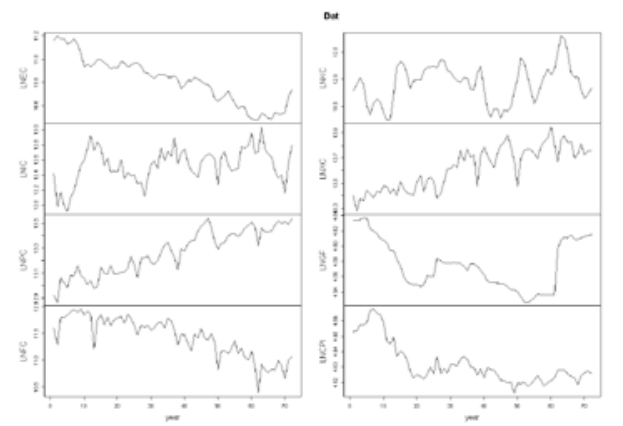

Fig. 1 Timing Diagram for LNEC, LNIC, LNPC, LNFC, LNKC, LNXC, LNGF, LNCPI

\subsection{Unit Root Test}

This paper uses ADF method to test the data stability, and the results are shown in the table below.

Table 1 Results of Unit Root Test

\begin{tabular}{|c|c|c|c|c|}
\hline Variable & $\begin{array}{c}\text { Inspection Type } \\
(\mathrm{A}, \mathrm{T}, \mathrm{P})\end{array}$ & Test Value of ADF & $\begin{array}{c}\text { The Corresponding } \\
\text { P value }\end{array}$ & $\begin{array}{c}\text { Test Results } \\
\text { (Stability of 1\%) }\end{array}$ \\
\hline LNEC & $(\mathrm{A}, \mathrm{T}, 1)$ & -2.4010 & 0.4121 & unstable \\
\hline LNIC & $(\mathrm{A}, 0,1)$ & 0.5582 & 0.7895 & unstable \\
\hline LNPC & $(\mathrm{A}, \mathrm{T}, 0)$ & -1.8475 & 0.3727 & unstable \\
\hline LNFC & $(\mathrm{A}, \mathrm{T}, 0)$ & -0.3045 & 0.5151 & unstable \\
\hline LNKC & $(\mathrm{A}, 0,0)$ & -2.4185 & 0.1634 & unstable \\
\hline LNXC & $(\mathrm{A}, \mathrm{T}, 0)$ & 0.4332 & 0.7497 & unstable \\
\hline LNGF & $(\mathrm{A}, 0,0)$ & -1.5947 & 0.4653 & unstable \\
\hline LNCPI & $(\mathrm{A}, 0,0)$ & -1.8147 & 0.3847 & unstable \\
\hline$\triangle$ LNEC & $(\mathrm{A}, \mathrm{T}, 1)$ & -5.6794 & 0.01 & stable \\
\hline$\triangle$ LNIC & $(\mathrm{A}, 0,1)$ & -6.5026 & 0.01 & stable \\
\hline$\triangle$ LNPC & $(\mathrm{A}, \mathrm{T}, 0)$ & -10.3132 & 0.01 & stable \\
\hline$\triangle$ LNFC & $(\mathrm{A}, \mathrm{T}, 0)$ & -10.2046 & 0.01 & stable \\
\hline$\triangle$ LNKC & $(\mathrm{A}, 0,0)$ & -5.1991 & 0.01 & stable \\
\hline$\triangle$ LNXC & $(\mathrm{A}, \mathrm{T}, 0)$ & -10.5770 & 0.01 & stable \\
\hline$\triangle$ LNGF & $(\mathrm{A}, 0,0)$ & -6.6050 & 0.01 & stable \\
\hline$\triangle$ LNCPI & $(\mathrm{A}, 0,0)$ & -10.5578 & 0.01 & stable \\
\hline
\end{tabular}

Note: $\triangle$ represents the first-order difference; $\mathrm{A}$ in $(\mathrm{A}, \mathrm{T}, \mathrm{P})$ represents a constant term, $\mathrm{T}$ represents the time trend, and $\mathrm{P}$ represents the hysteresis order. 
As can be seen from Table 1, the first-order differences of LNEC, LNIC, LNPC, LNFC, LNKC, LNXC, LNGF and LNCPI are stable at 1\% significance level. That is, all variables are first-order single I (1), so granger test can be conducted.

\subsection{Granger Test}

LNEC, LNIC, LNPC, LNKC, LNXC, LNGF and LNCPI are all integrated of order 1 which means the preconditions for granger test are satisfied. Johansen's characteristic root test method is used for the granger of the supply and demand respectively. The null hypothesis is $\mathrm{H}_{0}$ : there are 0 granger relation, $r=0$ means no granger relationship, $r=1,2,3$ or 4 means that there are at most $1,2,3$, or 4 granger relations.

Table 2 Johansen Granger Test for Supply

\begin{tabular}{|c|c|c|c|c|}
\hline \multirow{2}{*}{$\mathrm{H}_{0}$} & \multirow{2}{*}{ Trace Statistics } & \multicolumn{3}{|c|}{ The Critical Value } \\
\cline { 3 - 5 } & & $90 \%$ & $95 \%$ & $99 \%$ \\
\hline $\mathrm{r}=0$ & 99.24 & 83.20 & 87.31 & 96.58 \\
\hline $\mathrm{r}=1$ & 58.68 & 59.14 & 62.99 & 70.05 \\
\hline $\mathrm{r}=2$ & 34.38 & 39.06 & 42.44 & 48.45 \\
\hline $\mathrm{r}=3$ & 16.07 & 22.76 & 25.32 & 30.45 \\
\hline $\mathrm{r}=4$ & 7.25 & 10.49 & 12.25 & 16.26 \\
\hline
\end{tabular}

Table 3 Johansen Granger Test for Demand

\begin{tabular}{|c|c|c|c|c|}
\hline \multirow{2}{*}{$\mathrm{H}_{0}$} & \multirow{2}{*}{ Trace Statistics } & \multicolumn{3}{|c|}{ The Critical Value } \\
\cline { 3 - 5 } & & $90 \%$ & $95 \%$ & $99 \%$ \\
\hline $\mathrm{r}=0$ & 70.14 & 59.14 & 62.99 & 70.05 \\
\hline $\mathrm{r}=1$ & 28.14 & 39.06 & 42.44 & 48.45 \\
\hline $\mathrm{r}=2$ & 14.16 & 22.76 & 25.32 & 30.45 \\
\hline $\mathrm{r}=3$ & 3.64 & 10.49 & 12.25 & 16.26 \\
\hline
\end{tabular}

The results of Table 2 and Table 3 show that there is a granger relationship between copper price and the supply and demand sequences at $10 \%, 5 \%$ and $1 \%$ significance levels, and there is a long-term and stable equilibrium relationship between them. OLS method is used to estimate the linear combination of supply and demand sequences respectively. The granger test equation between LNEC, LNIC, LNPC, LNFC and LNKC is obtained:

$$
\begin{aligned}
& L N E C=\underset{1.1 .889}{17.5035}-\underset{0.0364}{0.1777} \operatorname{LNIC}-\underset{0.0644}{0.5144} \operatorname{LNPC}+\underset{0.0305}{0.2553} \operatorname{LNFC}-\underset{0.0241}{0.0468} L N K C+\varepsilon_{\mathrm{t}} \\
& \begin{array}{lllcl}
1.1889 & 0.0364 & 0.0644 & 0.0305 & 0.0241 \\
14.723 & -4.877 & -7.991 & 8.381 & -1.943
\end{array} \\
& \text { Adj }-R \text {-Squared }=0.8953 \quad F-\text { statistic }=152.8 \quad D W=0.8137
\end{aligned}
$$

The granger test equation featuring the relationship of LNEC, LNXC, LNGF, and LNCPI is

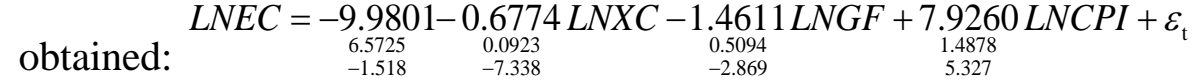

$$
\text { Adj-R-Squared }=0.7678 \quad F \text {-statistic }=79.26 \quad D W=0.641
$$

By the granger test, it can be seen that regression equation (1), (2) are meaningful. From regression equation (1), it can be seen that refined copper imports, refined copper production and scrap copper imports have a significant long-term impact on copper price, while the long-term impact of copper stocks in the Shanghai Futures Exchange on copper prices is weaker. From regression equation (2), it can be seen that refined copper consumption, real estate investment and CPI all have significant long-term effects on the price of copper.

\subsection{Granger Test of Causality}

The Johansen granger test shows that copper prices have a long-term and stable equilibrium relationship with supply and demand sequences, but it cannot tell the exact economic meaning between the various variables, so whether they constitute a causal relationship needs further verification. Since the supply and demand sequences are unstable, Granger causality test is used to test the causal relationship among the first-order difference sequences of each variable. 
Table 4 Granger Causality Test for Supply

\begin{tabular}{|l|l|l|}
\hline \multicolumn{1}{|c|}{ Null Hypothesis: } & F-Statistic & $\operatorname{Pr}(>\mathrm{F})$ \\
\hline Electrolytic copper prices are not the Granger cause of refined copper imports & 3.13 & 0.03 \\
\hline Refined copper imports are not the Granger cause of electrolytic copper prices & 1.3128 & 0.3005 \\
\hline Electrolytic copper prices are not the Granger cause of refined copper production & 0.5550 & 0.6467 \\
\hline Refined copper production is not the Granger cause of electrolytic copper prices & 3.1794 & 0.03 \\
\hline Electrolytic copper price is not Granger reason for the amount of copper scrap imports & 0.8502 & 0.4719 \\
\hline $\begin{array}{l}\text { The value of copper scrap imported is not the Granger cause of electrolytic copper } \\
\text { prices }\end{array}$ & 5.2429 & 0.0028 \\
\hline $\begin{array}{l}\text { Electrolytic copper prices are not Granger causes for Shanghai Futures Exchange } \\
\text { copper inventories }\end{array}$ & 1.2766 & 0.2904 \\
\hline $\begin{array}{l}\text { Shanghai Futures Exchange Copper inventories are not the Granger cause of } \\
\text { electrolytic copper prices }\end{array}$ & 1.7228 & 0.1717 \\
\hline
\end{tabular}

Table 4 shows that, at 5\% significance level, electrolytic copper price is Granger reason of refined copper imports , but refined copper imports are not the Granger cause of electrolytic copper price; electrolytic copper price is not Granger cause of refined copper production, but refining Copper production is the Granger cause of electrolytic copper price; electrolytic copper price is not the Granger cause of scrap copper import value, but the amount of copper scrap imported is the Granger cause of electrolytic copper price; electrolytic copper price is not Granger reason of copper inventory in Shanghai Futures Exchange; copper inventory in Shanghai Futures Exchange is not Granger reasons for electrolytic copper prices. Therefore, the price of electrolytic copper is influenced by the amount of refined copper produced and the amount of copper scrap imported. However, the refined copper imports and the copper futures of the Shanghai Futures Exchange have not affected the price of electrolytic copper. In addition, the price of electrolytic copper affects the import of refined copper but does not affect the output of refined copper. The price of electrolytic copper does not affect the import amount of scrap copper and the copper stock of Shanghai Futures Exchange.

Table 5 Granger Causality Test of Demand Sequence

\begin{tabular}{|l|l|l|}
\hline Null Hypothesis: & F-Statistic & $\operatorname{Pr}(>\mathrm{F})$ \\
\hline Electrolytic copper prices are not the Granger cause of refined copper consumption & 0.8810 & 0.4561 \\
\hline Refined copper consumption is not the Granger cause of electrolytic copper prices & 0.2063 & 0.8916 \\
\hline Electrolytic copper prices are not the Granger cause of real estate investment & 1.1341 & 0.3425 \\
\hline Real estate investment is not the Granger cause of electrolytic copper prices & 1.0106 & 0.3943 \\
\hline Copper price is not a Granger cause of CPI & 2.4531 & 0.0446 \\
\hline CPI is not the Granger cause of electrolytic copper prices & 0.3623 & 0.8721 \\
\hline
\end{tabular}

Table 5 shows that, at 5\% significance level, electrolytic copper price is not the Granger cause of refined copper consumption and refined copper consumption is not Granger cause of electrolytic copper price; electrolytic copper price is not Granger cause of real estate investment; real estate investment is not Granger causes of electrolytic copper prices; electrolytic copper price is Granger cause of CPI but CPI is not the Granger cause of electrolytic copper price. Therefore, the price of electrolytic copper has not been affected by refined copper consumption, real estate investment and CPI. However, as an important industrial raw material, electrolytic copper is directly used in the wire and cable, electronics industry, air-conditioners, automobiles and other consumer goods industries. When the price of electrolytic copper changes, it is bound to affect the price of the above consumer products industry, thus affecting the CPI.

\subsection{Error Correction Model}

Granger equation can only reflect the long-term dynamic relationship between electrolytic copper price and supply and demand sequences, but cannot reflect the short-term fluctuations between them. Therefore, error correction model should be created to reflect the short-term fluctuations. Through the co-integration test, the residual sequence is obtained, and the error correction term $E C M_{t}$ is the residual sequence. D represents the first-order difference, so the error correction model is established.

Error correction model between electrolytic copper price and supply sequence is created as follows: 


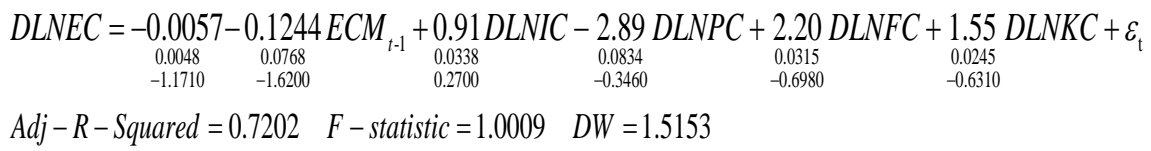

The coefficient of the above error correction term is -0.1244 , which conforms to the error reverse correction mechanism, reflecting that the number of deviations from the long-term equilibrium in the previous period will be reversed by $12.44 \%$ in the next period. The above equation shows that while other conditions remain unchanged, imports of refined copper increases by $1 \%$, electrolytic copper prices increases by $0.91 \%$ on average; refined copper production increases by $1 \%$, electrolytic copper prices decreases by $2.89 \%$ on average; scrap copper imports increases by $1 \%$, electrolytic copper price increases by an average of 2.20\%; copper inventory in Shanghai Futures Exchange, increases by $1 \%$, the average price of electrolytic copper increases by $1.55 \%$.

Error correction model between electrolytic copper price and demand sequence is created as follows:

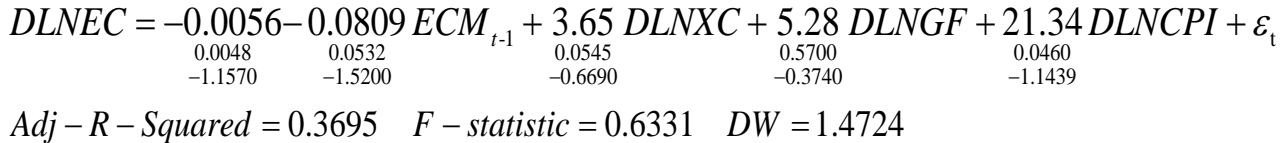

The coefficient of the above error correction term is -0.0809 , which conforms to the error reverse correction mechanism, reflecting that the number of deviations from the long-term equilibrium in the previous period will be reversed by $8.09 \%$ in the next period. The above formula shows that while other conditions remain unchanged, refined copper consumption increases by $1 \%$, electrolytic copper prices increase by $3.65 \%$ on average; real estate investment increases by $1 \%$, electrolytic copper prices increase by $5.28 \%$ on average; CPI increases by $1 \%$ and electrolytic copper prices increase on average $21.34 \%$. CPI has the greatest impact on the price of electrolytic copper and the change has a profound impact on the price of copper.

\section{Conclusion}

From the empirical analysis we can draw the following conclusions:

(I) There is a long-term and stable equilibrium relationship between the price of copper and the supply and demand sequences. Except for the weak long-term effect of the copper stocks of the Shanghai Futures Exchange on the price of copper, the remaining variables (refined copper imports, refined copper output, copper scrap Import Value, Refined Copper Consumption, Real Estate Investment, CPI) all have significant long-term effects on copper prices.

(II) The copper price is affected by the refined copper output and the scrap import value while the refined copper import volume and the Shanghai Futures Exchange copper stock have a weaker effect on the copper price. Copper price affects refined copper imports and CPI. Refined copper consumption, real estate investment has a weaker impact on copper price.

(III) The deviation from the long-run equilibrium with the previous supply sequence will get $12.44 \%$ of the reverse correction in the next period. The deviation from the long-run equilibrium with the previous demand sequence will get $8.09 \%$ of the reverse correction in the next period. CPI has the greatest impact on electrolytic copper price and a change of $1 \%$ will change the price of copper by 21.34\%.

\section{References}

[1]. Chen Fang, Huang Jianbai, Zhang Kun. Study on the Impact Mechanism of Copper Price Fluctuation in China Based on Supply and Demand Factors. Statistics and Decision, 2013 (18).

[2]. Wang Zhigang. An Empirical Analysis of the Impact of "China Factors" on International Copper Prices. Policy Theory and Practice, 2013 (11).

[3]. Yu Wenjia, Wang Gaoshang, Wang Anjian. Comparison of Domestic and Foreign Copper Futures Market and Reasonable Interval of Copper Price. Acta Geoscience Sinica, 2010 (5). 
[4]. Zhang Hao. Analysis and Prediction of Copper Price Regression Based on China Factors. Mining Technology, 2013 (4). 